\title{
PERANCANGAN WEB PORTAL PEMBELAJARAN HADITS ARBA'IN NAWAWI SEBAGAI MEDIA PENUNJANG PEMBELAJARAN SANTRI
}

\author{
Yulianti, Sri Lestanti, Ni'ma Kholila \\ Program Studi Teknik Informatika S1, Fakultas Teknologi Informasi \\ Universitas Islam Balitar, Jalan Majapahit Blitar, Indonesia \\ yulianti.yuly@gmail.com
}

\begin{abstract}
ABSTRAK
Teknologi menjadi salah hal yang mempengaruhi kehidupan manusia saat ini, karena teknologi mempermudah aktivitas manusia terlebih pada masa pandemi Covid-19 ini. Pembelajaran yang kurang baik dan kurang efektif merupakan salah satu masalah yang dihadapi pada masa pandemi ini, terutama pembelajaran para santri, karena dikhawatirkan salah pemahaman dalam mempelajari. Berdasarkan hal ini maka perlu dibuat sebuah web portal pembelajaran Hadits Arba'in Nawawi yang dapat mempermudah santri dalam mempelajari hadits pada masa Covid-19 ini. Penelitian ini merancang aplikasi pembelajaran hadits berbasis web yang dapat membantu para santri dalam mempelajari hadits meskipun tidak melakukan pembelajaran secara langsung. Pada aplikasi ini dilengkapi dengan fitur-fitur seperti audio hadits, pencarian hadits, dan juga latihan soal. Pada fitur pencarian hadits menerapkan algoritma Knuth-Morris-Pratt yang dapat menemukan kata-kata dalam hadits dengan mudah. Hasil dari penelitian ini ialah aplikasi pembelajaran hadits Arba'in Nawawi berbasis web yang dapat menjadi penunjang pembelajaran santri pada masa Covid-19 ini. Uji kelayakan aplikasi pada penelitian ini menggunakan pengujian Blackbox dan menghasilkan presentase kesesuaian sebesar $100 \%$ dan hasil pengujian terhadap pengguna dan pakar materi mendapatkan hasil presentase setuju sebesar $45 \%$ dan sangat setuju sebesar $55 \%$ yang berarti dengan adanya aplikasi pembelajaran ini dapat membantu menunjang pembelajaran santri.
\end{abstract}

Kata kunci : web portal pembelajaran, hadits arba'in nawawi, knuth-morris-pratt, blackbox

\section{PENDAHULUAN}

\subsection{Latar Belakang}

Penduduk Indonesia mayoritas beragama Islam, yang mana dalam kehidupan sehari-harinya membutuhkan pedoman agar terus berpegang teguh pada agama Islam sesuai dengan tuntunan Allah SWT dan Rasul-Nya. Ada empat sumber hukum dalam Islam yaitu Al-Qur'an, Hadits, ljma' dan Qiyas. Tanpa menggunakan hadits hukum Islam tidak dapat dipahami dan dijalankan secara sempurna sebab sumber hukum kedua ialah hadits.

Hadits Arba'in Nawawi ialah salah satu dari sekian banyak kitab yang didalamnya berisi 42 hadits pilihan yang dikenal luas di kalangan para cendikiawan muslim Indonesia, dan tentunya di seluruh dunia Islam. Kitab hadits Arba'in AnNawawi banyak dipelajari di pondok-pondok pesantren oleh sebab itu kitab tersebut terus berkembang mulai dari metode yang digunakan dan bentuk yang digunakan. Para santri dianjurkan terlebih dahulu harus mempelajari dan memahami hadits arbai'n sebelum lanjut mempelajari kitab hadits yang lain.

Ada beberapa alasan mengapa kitab hadits Arba'in An-Nawawi harus dipelajari dan dipahami, yaitu kitab ini didalamnya merupakan kumpulan hadits-hadits nabi pilihan yang sebagian besar kandungannya meliputi segala hal dan keperluan kaum muslimin didunia dan di akhirat mulai dari hukum, aqidah, akhlak, syariah dan muamalah. Kitab ini disebut jawami'ul kalim yang berarti didalamnya memiliki pokok-pokok bahasan yang singkat dan padat namun mengandung banyak makna [1].

Pembelajaran hadits akan berjalan efektif apabila pembelajaran tersebut disampaikan secara langsung oleh pengajar atau ustadz sehingga tidak ada kekeliruan dalam memahami hadits tersebut. Salah satu hal yang menentukan efektivitas pembelajaran jarak jauh yaitu teknologi. Oleh sebab itu, dibutuhkan sebuah portal pembelajaran khusus supaya proses pembelajaran tetap berjalan dengan baik, terutama pada pembelajaran hadits arba' in.

Teknologi yang masih berkembang saat ini sangat berpengaruh terhadap kehidupan manusia pada masa ini, terutama di masa pandemi ini. Berbagai kemudahan dapat kita peroleh dalam hal komunikasi dan akses informasi karena hadirnya teknologi informasi. Tidak terkecuali juga dalam hal keagamaan, teknologi dapat berperan dalam menunjang persoalan-persoalan keagamaan. Dengan adanya teknologi informasi maka persoalan keagamaan dapat dipermudah karena para santri bisa mendapatkan informasi yang dibutuhkan agar tidak salah pemahaman. Oleh sebab itu dibuatlah sebuah web portal pembelajaran Hadits Arba'in Nawawi yang didalamnya menyajikan 42 hadits arba'in nawawi, pencarian hadits, audio hadits, dan latihan soal-soal yang berkaitan dengan hadits guna mempermudah santri dalam mempelajari hadits di masa Covid-19 ini.

Penelitian yang telah dilakukan dengan topik pencarian dengan menerapkan algoritma KnuthMorris-Pratt ialah tentang pencarian surah dalam Al- 
Qur'an oleh Syarif (2017). Pada sistem aplikasi pencarian ayat dalam Al-Qur'an ini menerapkan konsep algoritma string matching dengan cara melakukan penyusuran kata yang terdapat pada AlQur'an secara keseluruhan. Membandingkan setiap text dan pattern dengan pola dari kiri ke kanan merupakan cara kerja algoritma ini [2].

Portal pembelajaran Hadits Arba'in Nawawi ini dibuat menggunakan sistem berbasis web dengan keunggulan pengguna tidak perlu melakukan proses instalasi, bersifat terpusat, dapat dijalankan pada berbagai macam sistem operasi asalkan mempunyai browser dan koneksi internet, dan tidak memerlukan spesifikasi komputer client yang tinggi. Aplikasi ini akan mempermudah para santri dalam penggunaannya karena disajikan dengan tampilan yang menarik dan mudah dipahami.

\subsection{Batasan Penelitian}

Berikut ini merupakan sejumlah batasan dalam penelitan yang ditetapkan oleh penulis :

a. Penelitian dikhususkan pada pembelajaran hadits yang sudah ditentukan sebelumnya yaitu hadits Arba'in Nawawi

b. Perancangan pembelajaran hadits ini berbasis web

c. Perancangan pembelajaran hadits ini menggunakan framework Codeigniter dan database MySQL

d. Aplikasi pembelajaran hadits ini menerapkan algoritma Knuth-Morris-Pratt pada fitur pencarian kata pada hadits

e. Pengujian aplikasi menggunakan Blackbox Testing.

\section{TINJAUAN PUSTAKA}

\subsection{Kajian Penelitian}

Pada penelitian yang dilakukan oleh Wahyuningsih \& Nurdiana (2016) yang membahas tentang Aplikasi Hadits dengan judul "Aplikasi Pencarian dan Pembelajaran Hadits Pada Kitab Riyadhus Sholihin Berbasis Mobile", diperoleh informasi bahwa sistem mobile seharusnya mampu menggantikan pembelajaran hadits manual sebab sistem pembelajaran hadits menggunakan papan tulis dan media buku dapat menimbulkan kebosanan. Pada aplikasi ini dilengkapi dengan pencarian kata dan mendengarkan hadits sehingga dapat memberikan kemudahan bagi pengguna aplikasi ini. Dengan aplikasi ini dapat menunjang proses pembelajaran dan pengetahuan hadits. Oleh sebab itu penulis tertarik untuk membuat aplikasi pembelajaran hadits yang didalamnya mencakup pembelajaran hadits dan audio hadits yang diharapkan dapat mempermudah para santri untuk mempelajari hadits, dan juga dilengkapi dengan soal-soal tentang hadits yang diharapkan dapat membantu para santri dalam mengingat hadits tersebut [3].

\subsection{Pembelajaran}

Hakikat dari pembelajaran ialah proses, yaitu proses-proses yang bisa mendorong dan menumbuhkan peserta didik agar melakukan proses pembelajaran, mulai dari mengatur dan mengontrol peserta didik. Dalam menjalankan proses belajar, memberikan bimbingan atau bantuan terhadap peserta didik juga termasuk dalam pembelajaran. Perbedaan sering ditemukan dalam proses pembelajaran, hal tersebut disebabkan oleh keadaan dari masing-masing peserta didik, mudah mengerti dan ada pula yang lamban dalam menyerap materi pembelajaran. Oleh karena itu, pengajar sangat berperan penting dalam merumuskan rencana pembelajaran yang efisien sesuai dengan kondisi dari peserta didik. Jadi, jika perubahan merupakan hakikat dari belajar maka pengaturan merupakan hakikat dari pembelajaran [4].

\subsection{Hadits Arba'in Nawawi}

Hadits merupakan perkataan, perilaku, dan ketetapan nabi Muhammad SAW. Secara etimologi hadits adalah perkataan, sebab hadits bersumber dari ucapan dan perilaku nabi Muhammad SAW, beliau adalah hamba Allah yang lebih mengetahui tentang isi Al-Quran, oleh sebab itu hadits ditetapkan sebagai sumber hukum kedua umat Islam. Sebagai umat islam dianjurkan untuk mempelajari, mengambil ibrah dan menghafal hadits-hadits ini karena mencakup ruang lingkup yang luas dalam kehidupan [5].

\subsection{Algoritma Knuth-Morris-Pratt}

Algoritma Knuth-Morris-Pratt ialah algoritma pencarian string yang dikembangkan berdasarkan algoritma sebelumnya yaitu algoritma Brute Force. Melakukan pencocokan string merupakan fungsi dari algoritma ini. Exact String Matching Algorithm ialah jenis dari algoritma ini, sebab algoritma ini melakukan pencocokan string dengan akurat menggunakan struktur karakter pada string yang dicocokan mempunyai kuantitas atau urutan karakter pada string yang sepadan [6].

\subsection{Pengujian Blackbox}

Metode pengujian Blackbox merupakan pengujian yang digunakan untuk memeriksa hasil eksekusi aplikasi menurut inputan yang diberikan untuk mengetahui fungsionalitas dari aplikasi telah sesuai dengan yang diharapkan [7]. Cara kerja dari Blackbox Testing adalah melakukan percobaan pada program yang sudah dirancang dengan cara menginputkan data dalam setiap formnya. Pengujian ini dibutuhkan guna mendeteksi tingkat fungsionalitas program, apakah sudah bekerja sesuai dengan yang diharapkan atau perlu adanya perbaikan [8]. 


\section{METODE PENELITIAN}

\subsection{Desain Penelitian}

Waterfall model merupakan metode rancang bangun yang diterapkan pada penelitian ini. Analisa, design, code, dan test merupakan empat langkah pada metode rancangan ini [9]. Desain penelitian ini dikerjakan berdasakan diagram alir pembuatan aplikasi pada gambar 1 berikut ini :

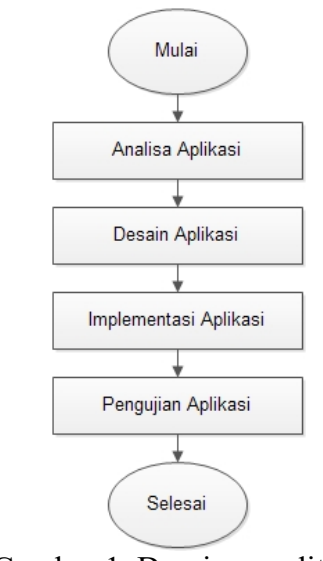

Gambar 1. Desain penelitian

Desain penelitian ini dibuat serta dijalankan secara berurutan yaitu mulai dari menganalisa kebutuhan aplikasi yang diperlukan, kemudian, mendesain aplikasi sesuai kebutuhan, kemudian mengimplementasikan hasil aplikasi, dan terakhir melakukan pengujian dari aplikasi guna mengetahui apakah aplikasi yang dibangun sesuai dengan yang diinginkan.

\subsection{Jenis dan Metode Pengumpulan Data}

Melakukan penelitian lapangan dan melakukan pemerikasaan secara langsung terhadap objek untuk memperoleh data yang dibutuhkan merupakan metode pengumpulan data yang diterapkan pada penelitian ini.

\section{a) Sumber Data Primer}

Data primer ialah data yang didapatkan secara langsung dari objek penelitian oleh penulis. Data tersebut berasal dari narasumber, data serta keterangan yang diperoleh didapatkan dengan cara berikut :

\section{1) Observasi}

Observasi dilakukan pada pihak-pihak yang terkait untuk memperoleh data secara umum dengan mengamati dan melihat langsung.

\section{2) Wawancara}

Peneliti melakukan wawancara dengan cara mengambil data-data yang dibutuhkan guna menyelesaikan masalah yang terjadi dan melakukan tanya jawab dengan pihak yang bersangkutan.

\section{b) Sumber Data Sekunder}

Data sekunder didapatkan secara tidak langsung terhadap objek penelitian. Memperoleh data-data yang berhubungan dengan penelitian melalui jurnal, buku-buku, publikasi pemerintah, maupun dari internet merupakan bagian dari sumber data sekunder yang gunanya sebagai bukti penelitian benar dilakukan pada instansi. Data sekunder ini digunakan untuk melegkapi data primer. Adapun sumber litelatur yang digunakan yaitu jurnal atau buku yang membahas tentang portal pembelajaran.

\subsection{Skema Metode Perancangan 3.3.1 Use Case Diagram}

Use case diagram ialah mekanisme pemodelan antara user dan aplikasi guna memberi gambaran aktifitas yang terjadi. Use case diagram yang digunakan dalam sistem ditampilkan pada gambar 2 dibawah ini.

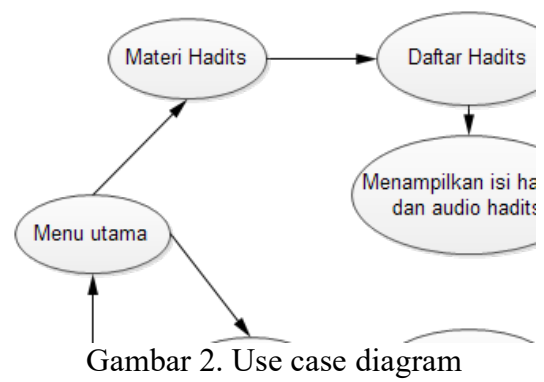

\subsubsection{Flowchart}

Flowchart adalah diagram yang menggambarkan langkah-langkah proses program secara rinci. Diagram alir yang digunakan dalam sistem ditunjukan pada gambar 3 .

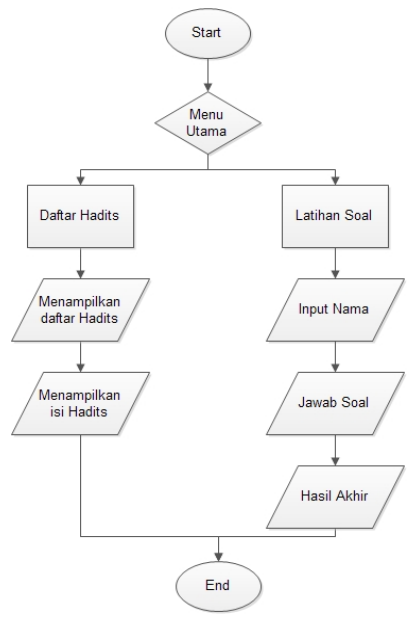

Gambar 3. Flowchart

\subsubsection{Diagram Konteks}

Diagram konteks merupakan diagram tingkat tinggi yang menggambarkan diagram aliran data dari data yang mengalir masuk dan keluar pada system, dan merupakan alat yang digunakan untuk melihat 
batas antara sistem dan entitas eksternal. Diagram konteks yang digunakan sistem ditampilkan pada gambar 4.

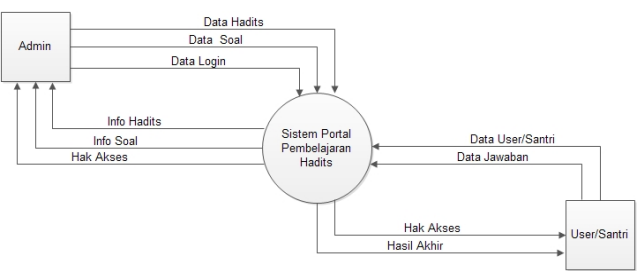

Gambar 4. Diagram konteks

\subsubsection{Entity Relationship Diagram (ERD)}

Perancangan ERD ini berguna untuk menggambarkan sistem berdasarkan alur hubungan antar entitas dalam tabel. Dalam desain ini, hanya beberapa tabel yang dapat berelasi. Oleh sebab itu, peneliti hanya menggambarkan bagian inti dari tabel yang dapat berelasi. Berikut ERD yang digunakan pada sistem ditampilkan pada gambar 5 .

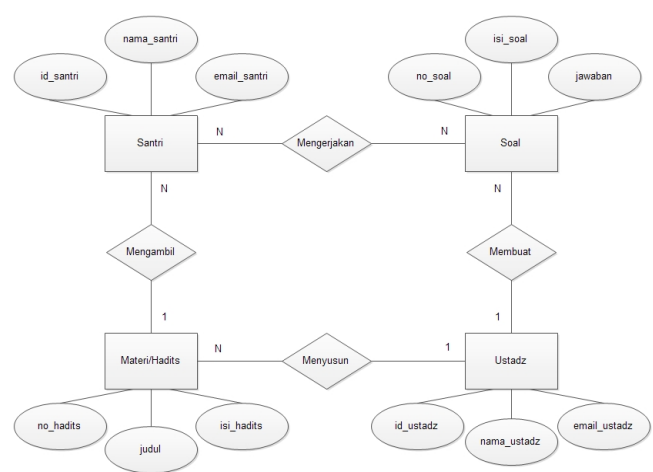

Gambar 5. Entity relationship diagram

\section{HASIL DAN PEMBAHASAN}

\subsection{Implementasi Tampilan Sistem}

Proses perancangan atau pengkodingan sistem dilakukan setelah proses analisis kebutuhan dan desain awal perancangan aplikasi telah dilakukan. Perancangan aplikasi ini dibuat menggunakan framework Codeigniter dan database yang digunakan adalah MySQL. Pada program aplikasi pembelajaran hadits ini terdiri dari beberapa halaman, diantaranya sebagai berikut :

\subsection{Halaman Utama}

Saat petama kali membuka aplikasi maka halam inilah yang akan muncul. Halaman utama ini memuat 2 button yaitu button login pada pojok kanan atas yang berguna untuk admin mengelola aplikasi pembelajaran hadits ini, dan ada button "Mulai Pembelajaran" pada bagian tengah yang gunanya untuk user mengakses aplikasi pembelajaran hadits ini. Adapun gambar tampilan halaman utama terdapat pada gambar 6 .

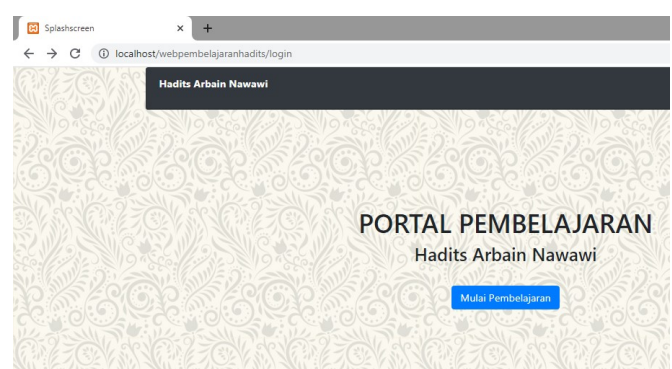

Gambar 6. Halaman utama

\subsection{Halaman Login}

Tampilan khusus admin, inilah sebutan untuk halaman ini, gunanya untuk melakukan kelola aplikasi pembelajaran hadits ini. Nama pengguna dan kata sandi yang telah terdaftar pada sistem database dibutuhkan admin untuk mengakses halaman admin. Adapun gambar tampilan halaman login terdapat pada gambar 7 .

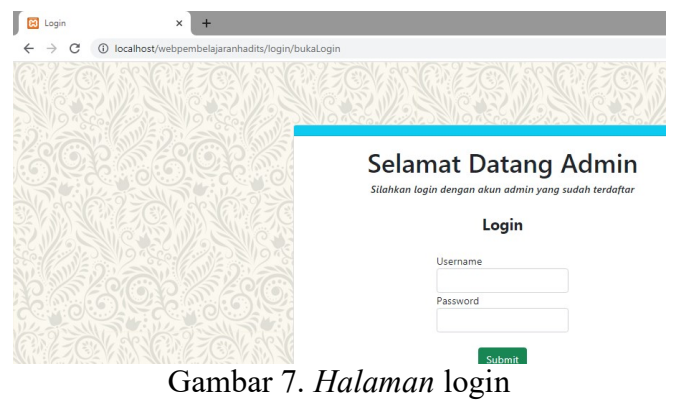

\subsection{Halaman Awal Untuk User}

Halaman awal untuk user ialah halaman yang akan ditampilkan setelah user mengklik button "Mulai Pembelajaran" pada halaman utama. Pada halaman awal ini user disajikan tampilan yang sederhana, terdapat 2 menu pilihan untuk user yaitu pilihan menu materi hadits dan latihan soal. Adapun gambar tampilan halaman awal untuk user terdapat pada gambar 8 .

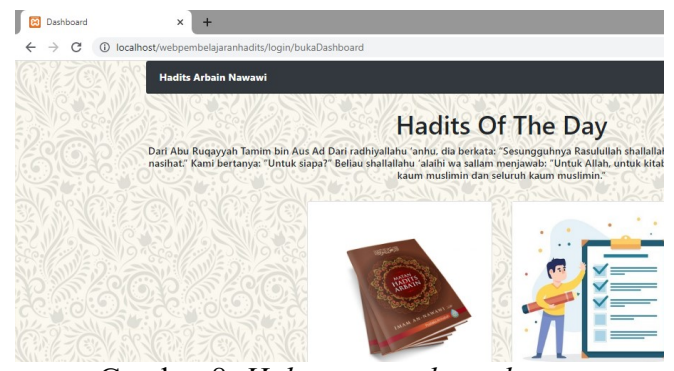

Gambar 8. Halaman awal untuk user

\subsection{Halaman Daftar Hadits}

Halaman daftar hadits adalah halaman yang memuat 42 judul hadits Arba'in Nawawi. Adapun gambar tampilan halaman daftar hadits terdapat pada gambar 9 . 


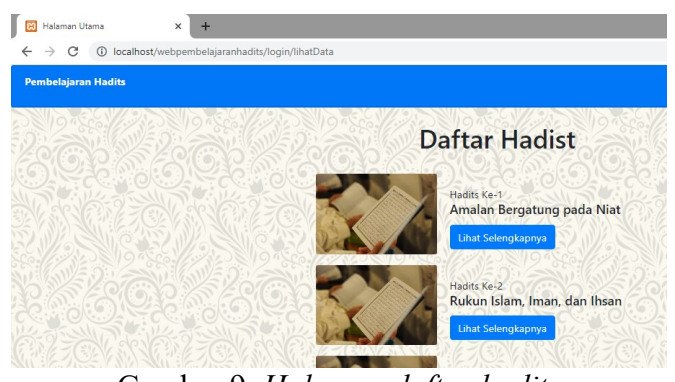

Gambar 9. Halaman daftar hadits

\subsection{Halaman Isi Hadits}

Halaman isi hadits adalah halaman yang menampilkan hadits yang telah dipilih pada halaman daftar hadits. Pada halaman ini terdapat hadits, terjemahan hadits, syarah hadits, dan juga audio hadits. Adapun gambar tampilan halaman isi hadits terdapat pada gambar 10 .

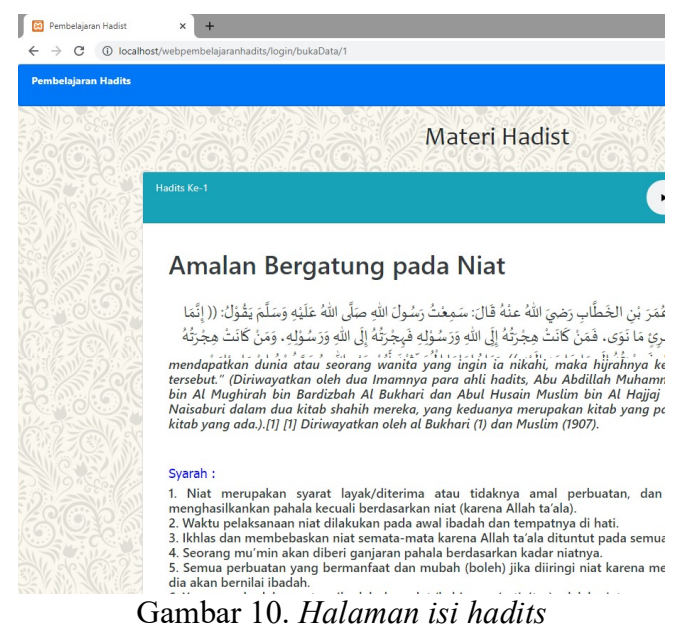

\subsection{Halaman Latihan Soal}

Halaman latihan soal ialah halaman yang memuat soal-soal terkait dengan hadits Arba'in Nawawi. Soal-soal pada halaman ini gunanya untuk mengevaluasi seberapa paham user dengan hadits yang telah dipelajari. Soal-soal pada halaman ini disesuaikan oleh admin. Pada latihan soal ini diberi timer dalam mengerjakan soal tersebut. Adapun gambar tampilan halaman latihan soal terdapat pada gambar 11.

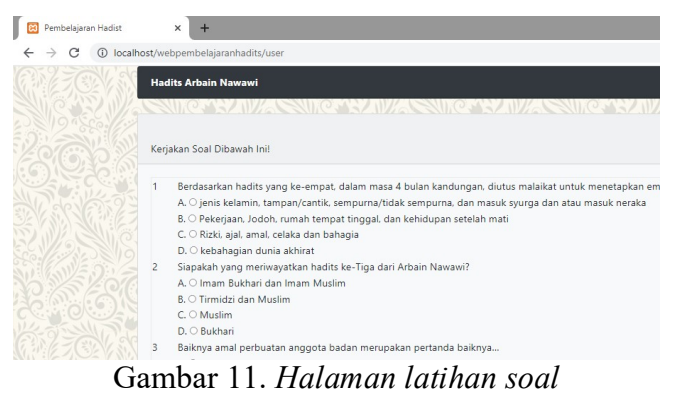

\subsection{Halaman Nilai Akhir}

Halaman nilai akhir ialah halaman yang ditampilkan setelah user selesai mengerjakan soalsoal latihan. Pada halaman ini terdapat jumlah skor berdasarkan hasil jawaban benar oleh user. Adapun gambar tampilan halaman nilai akhir terdapat pada gambar 12 .

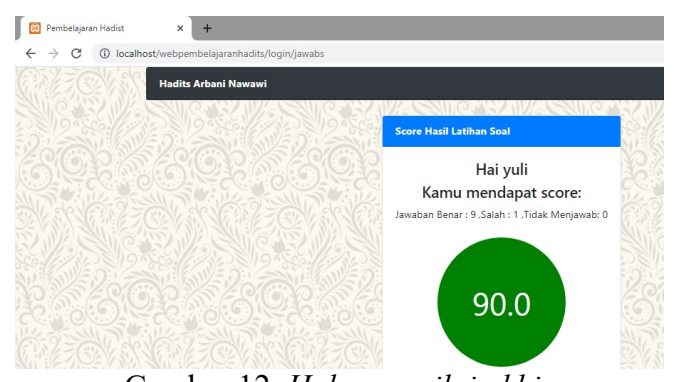

Gambar 12. Halaman nilai akhir

\subsection{Halaman Data Hadits}

Halaman data hadits adalah halaman yang didalamnya terdapat data-data hadits mulai dari hadits, terjemahan, syarah, dan juga audio hadits. Halaman ini hanya ditampilkan untuk admin yang sudah melakukan login pada aplikasi pembelajaran ini. Adapun gambar tampilan halaman data hadits terdapat pada gambar 13 .

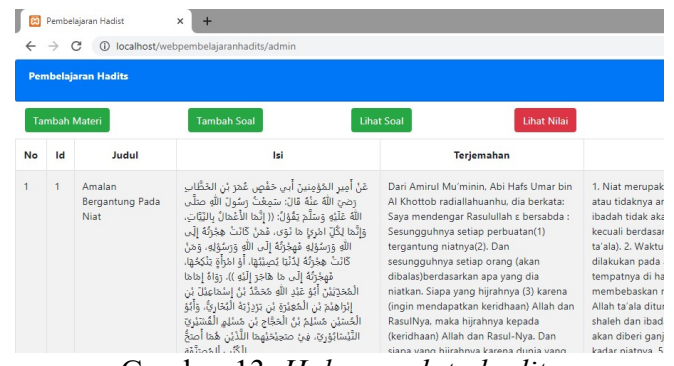

Gambar 13. Halaman data hadits

\subsection{Halaman Data Soal}

Halaman data soal juga sama dengan halaman data hadits yang mana halaman ini adalah halaman yang ditampilkan untuk admin yang telah melakukan login. Pada halaman ini terdapat data-data soal yang sifatnya bisa diubah dan dihapus. Adapun gambar tampilan halaman data soal terdapat pada gambar 14.

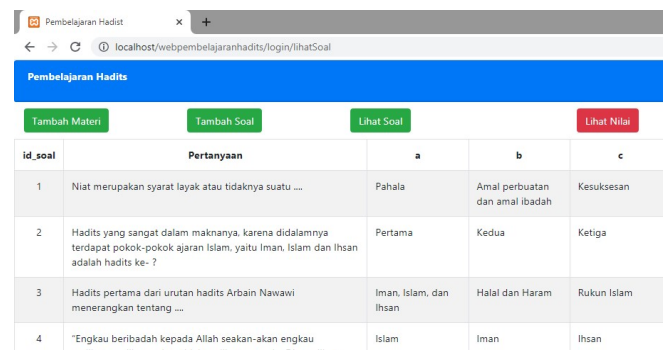

Gambar 14. Halaman data soal 


\subsection{Halaman Data Nilai}

Halaman data nilai adalah halaman yang menyajikan nilai-nilai hasil dari pengerjaan latihan soal. Halaman ini menampilkan data nama, kelas dan juga nilai hasil. Adapun gambar tampilan halaman data nilai terdapat pada gambar 15 .

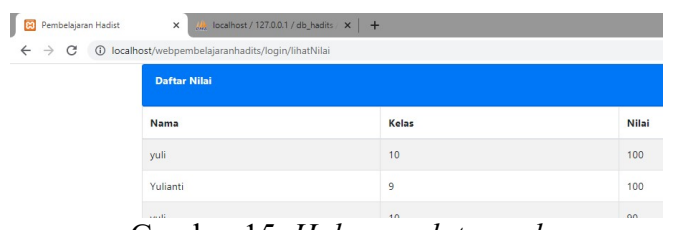

Gambar 15. Halaman data soal

\subsection{Implementasi Algoritma Knuth-Morris-Pratt}

Implementasi algoritma Knuth-Morris-Pratt dibuat pada file cari.php. Adapun beberapa source code file tersebut terdapat pada gambar berikut.

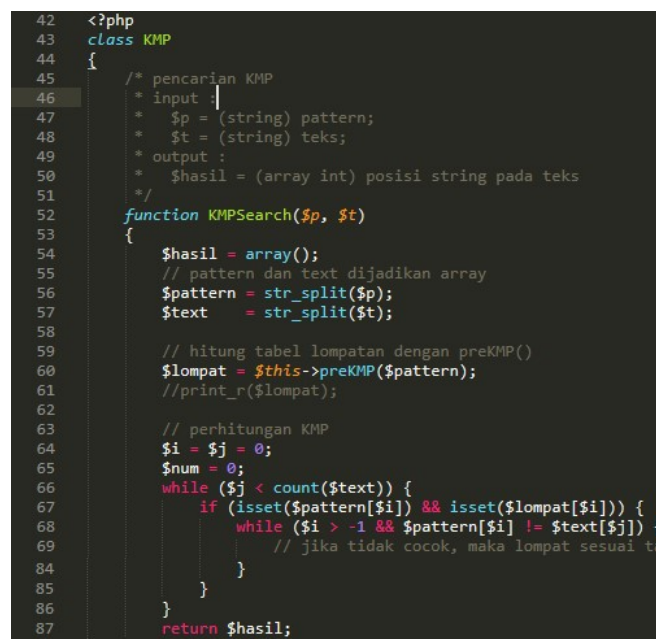

Gambar 16. Source code algoritma knuth-morrispratt (1)

Penggalan source code pada gambar 16 merupakan source code yang berfungsi untuk menjalankan pencarian dengan menerapkan algoritma Knuth-Morris-Pratt. Perhitungan yang terjadi pada algoritma ini yaitu jika pattern tidak cocok dengan text maka lompat sesuai dengan tabel lompatan, dan jika cocok maka akan ditentukan posisi string yang cocok dan kemudian lompat ke string berikutnya.

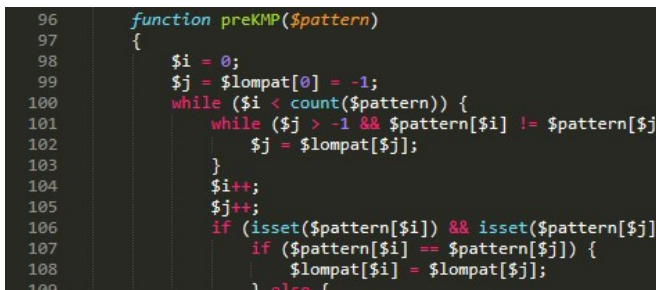

Gambar 17. Source code algoritma knuth-morrispratt (2)
Penggalan source code pada gambar 17 merupakan source code yang digunakan untuk melakukan sorting yang gunanya untuk menentukan tabel lompatan pada algoritma Knuth-Morris-Pratt.

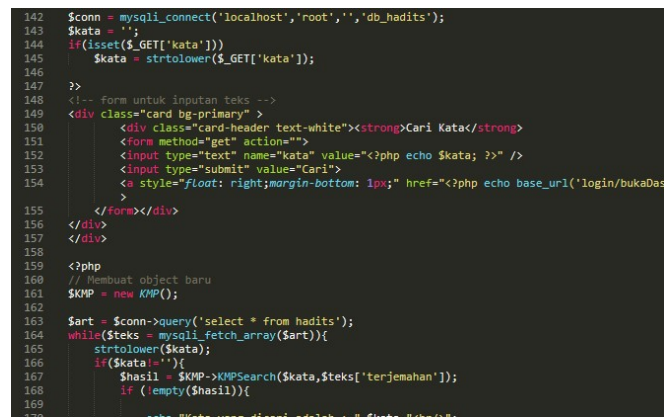

Gambar 18. Source code algoritma knuth-morrispratt (3)

Penggalan source code pada gambar 18 merupakan source code yang digunakan untuk menampilkan data hasil pencarian. Ketika tidak menemukan kata yang cocok maka algoritma akan menampilkan halaman kosong.

\subsection{Pengujian Blackbox}

Hasil pengujian pada halaman utama terdapat pada tabel 1 .

Tabel 1. Hasil pengujian pada halaman utama

\begin{tabular}{|c|c|c|c|}
\hline $\begin{array}{l}\text { Hal Yang } \\
\text { Dilakukan }\end{array}$ & Pengujian & $\begin{array}{c}\text { Kondisi } \\
\text { Yang } \\
\text { Diinginkan }\end{array}$ & Hasil Pengujian \\
\hline $\begin{array}{l}\text { Klik tombol } \\
\text { login }\end{array}$ & $\begin{array}{l}\text { Menampilkan } \\
\text { halaman login }\end{array}$ & $\begin{array}{l}\text { Halaman } \\
\text { login tampil }\end{array}$ & {$\left[\begin{array}{l}{[\sqrt{ }] \text { berhasil }} \\
{[\quad] \text { tidak berhasil }}\end{array}\right.$} \\
\hline $\begin{array}{l}\text { Klik halaman } \\
\text { selanjutnya }\end{array}$ & $\begin{array}{l}\text { Menampilkan } \\
\text { halaman } \\
\text { selanjutnya }\end{array}$ & $\begin{array}{l}\text { Halaman } \\
\text { selanjutnya } \\
\text { berupa } \\
\text { halaman } \\
\text { awal untuk } \\
\text { user tampil }\end{array}$ & $\begin{array}{l}{[\sqrt{ }] \text { berhasil }} \\
{[\text { ] tidak berhasil }}\end{array}$ \\
\hline
\end{tabular}

Hasil pengujian pada halaman login terdapat pada tabel 2 .

Tabel 2. Hasil pengujian pada halaman login

\begin{tabular}{|l|l|l|l|}
\hline $\begin{array}{l}\text { Hal Yang } \\
\text { Dilakukan }\end{array}$ & \multicolumn{1}{|c|}{ Pengujian } & $\begin{array}{c}\text { Kondisi } \\
\text { Yang } \\
\text { Diinginkan }\end{array}$ & Hasil Pengujian \\
\hline $\begin{array}{l}\text { Klik } \\
\text { tombol } \\
\text { submit }\end{array}$ & $\begin{array}{l}\text { Masukan } \text { username } \\
\text { benar dan password } \\
\text { benar, kemudian } \\
\text { klik submit }\end{array}$ & $\begin{array}{l}\text { Halaman } \\
\text { untuk admin } \\
\text { tampil }\end{array}$ & $\begin{array}{l}{[\sqrt{ } \text { ] berhasil }} \\
{[\text { ] tidak berhasil }}\end{array}$ \\
\hline $\begin{array}{l}\text { Klik } \\
\text { tombol } \\
\text { submit } \\
\text { benar dan password } \\
\text { salah, kemudian } \\
\text { klik submit }\end{array}$ & $\begin{array}{l}\text { Gagal } \\
\text { menampilkan } \\
\text { halaman } \\
\text { admin }\end{array}$ & {$\left[\begin{array}{l}{[\sqrt{ }] \text { berhasil }} \\
{[\text { ] tidak berhasil }}\end{array}\right.$} \\
\hline $\begin{array}{l}\text { Klik } \\
\text { tombol } \\
\text { submit }\end{array}$ & $\begin{array}{l}\text { Masukan } \text { username } \\
\text { benar dan password } \\
\text { kosong, kemudian } \\
\text { klik submit }\end{array}$ & $\begin{array}{l}\text { Gagal } \\
\text { menampilkan } \\
\text { halaman } \\
\text { admin }\end{array}$ & $\begin{array}{l}{[\sqrt{ }] \text { berhasil }} \\
{[\quad] \text { tidak berhasil }}\end{array}$ \\
\hline $\begin{array}{l}\text { Klik } \\
\text { tombol } \\
\text { submit }\end{array}$ & $\begin{array}{l}\text { Masukan } \text { username } \\
\text { salah dan password } \\
\text { benar, kemudian }\end{array}$ & $\begin{array}{l}\text { Gagal } \\
\text { menampilkan } \\
\text { halaman }\end{array}$ & $\begin{array}{l}{[\sqrt{ }] \text { berhasil }} \\
{[\text { ] tidak berhasil }}\end{array}$ \\
\hline
\end{tabular}




\begin{tabular}{|l|lr|l|l|}
\hline & klik submit & admin & \\
\hline Klik & Masukan & username & Gagal & {$[\sqrt{ }]$ berhasil } \\
tombol & kosong dan & menampilkan & {$[$ ] tidak berhasil } \\
submit & $\begin{array}{l}\text { password renar, } \\
\text { kemudian ralaman }\end{array}$ & klik & admin & \\
& submit & & & \\
\hline
\end{tabular}

Hasil pengujian pada halaman awal terdapat pada tabel 3 .

Tabel 3. Hasil Pengujian Pada Halaman Awal

\begin{tabular}{|c|c|c|l|}
\hline $\begin{array}{c}\text { Hal Yang } \\
\text { Dilakukan }\end{array}$ & Pengujian & $\begin{array}{c}\text { Kondisi Yang } \\
\text { Diinginkan }\end{array}$ & Hasil Pengujian \\
\hline $\begin{array}{c}\text { Klik tombol } \\
\text { Hadits }\end{array}$ & $\begin{array}{c}\text { Menampilkan } \\
\text { halaman daftar } \\
\text { hadits }\end{array}$ & $\begin{array}{c}\text { Halaman daftar } \\
\text { hadits tampil }\end{array}$ & $\begin{array}{l}{[\sqrt{ }] \text { berhasil }} \\
{[\text { ] tidak berhasil }}\end{array}$ \\
\hline $\begin{array}{c}\text { Klik tombol } \\
\text { Latihan Soal }\end{array}$ & $\begin{array}{c}\text { Menampilkan } \\
\text { halaman latihan } \\
\text { soal }\end{array}$ & $\begin{array}{c}\text { Halaman } \\
\text { latihan soal } \\
\text { tampil }\end{array}$ & $\begin{array}{l}{[\sqrt{ }] \text { berhasil }} \\
{[\text { ] tidak berhasil }}\end{array}$ \\
\hline
\end{tabular}

Hasil pengujian pada halaman daftar hadits terdapat pada tabel 4.

Tabel 4. Hasil Pengujian Pada Halaman Daftar Hadits

\begin{tabular}{|c|c|c|c|}
\hline $\begin{array}{l}\text { Hal Yang } \\
\text { Dilakukan }\end{array}$ & Pengujian & $\begin{array}{c}\text { Kondisi } \\
\text { Yang } \\
\text { Diinginkan }\end{array}$ & Hasil Pengujian \\
\hline Klik Daftar Hadits & $\begin{array}{c}\text { Menampilkan } \\
\text { halaman isi } \\
\text { hadits }\end{array}$ & $\begin{array}{c}\text { Halaman isi } \\
\text { hadits } \\
\text { tampil }\end{array}$ & $\begin{array}{l}{[\sqrt{ }] \text { berhasil }} \\
{[\text { ] tidak berhasil }}\end{array}$ \\
\hline $\begin{array}{l}\text { Klik pencarian } \\
\text { hadits }\end{array}$ & $\begin{array}{c}\text { Menampilkan } \\
\text { hasil } \\
\text { pencarian }\end{array}$ & $\begin{array}{c}\text { Hasil } \\
\text { pencarian } \\
\text { ditampilkan }\end{array}$ & $\begin{array}{l}{[\checkmark] \text { berhasil }} \\
{[\text { ] tidak berhasil }}\end{array}$ \\
\hline
\end{tabular}

Hasil pengujian pada halaman isi hadits terdapat pada tabel 5 .

Tabel 5. Hasil Pengujian Pada Halaman Isi Hadits

\begin{tabular}{|c|c|c|c|}
\hline $\begin{array}{c}\text { Hal Yang } \\
\text { Dilakukan }\end{array}$ & Pengujian & $\begin{array}{c}\text { Kondisi } \\
\text { Yang } \\
\text { Diinginkan }\end{array}$ & Hasil Pengujian \\
\hline $\begin{array}{c}\text { Klik } \\
\text { kembali }\end{array}$ & $\begin{array}{c}\text { Menampilkan } \\
\text { halaman sebelumnya } \\
\text { yaitu daftar hadits }\end{array}$ & $\begin{array}{c}\text { Halaman } \\
\text { sebelumnya } \\
\text { ditampilkan }\end{array}$ & $\begin{array}{c}{[\sqrt{ }] \text { berhasil }} \\
{[\text { ] tidak berhasil }}\end{array}$ \\
\hline $\begin{array}{c}\text { Klik } \\
\text { selanjutnya }\end{array}$ & $\begin{array}{c}\text { Menampilkan } \\
\text { halaman selanjutnya } \\
\text { yaitu berupa hadits } \\
\text { selanjutnya }\end{array}$ & $\begin{array}{c}\text { Halaman } \\
\text { selanjutnya } \\
\text { ditampilkan }\end{array}$ & $\begin{array}{l}{[\sqrt{ }] \text { berhasil }} \\
{[\text { ] tidak berhasil }}\end{array}$ \\
\hline $\begin{array}{c}\text { Klik icon } \\
\text { audio } \\
\text { hadits }\end{array}$ & $\begin{array}{c}\text { Memutar audio hadits } \\
\text { hadits } \\
\text { diputar }\end{array}$ & $\begin{array}{l}{[\sqrt{ }] \text { berhasil }} \\
{[\text { ] tidak berhasil }}\end{array}$ \\
\hline
\end{tabular}

Hasil pengujian pada halaman latihan soal terdapat pada tabel 6 .

Tabel 6. Hasil Pengujian Pada Halaman Latihan Soal

\begin{tabular}{|c|c|c|c|}
\hline $\begin{array}{c}\text { Hal Yang } \\
\text { Dilakukan }\end{array}$ & Pengujian & $\begin{array}{c}\text { Kondisi Yang } \\
\text { Diinginkan }\end{array}$ & Hasil Pengujian \\
\hline $\begin{array}{c}\text { Klik } \\
\text { selanjutnya }\end{array}$ & $\begin{array}{c}\text { Menmpilkan soal } \\
\text { selanjutnya }\end{array}$ & $\begin{array}{c}\text { Soal } \\
\text { selanjutnya } \\
\text { tampil }\end{array}$ & $\begin{array}{l}{[\sqrt{ }] \text { berhasil }} \\
{[\text { ] tidak berhasil }}\end{array}$ \\
\hline
\end{tabular}

Hasil pengujian pada halaman nilai akhir terdapat pada tabel 7 .

Tabel 7. Hasil Pengujian Pada Halaman Nilai Akhir

\begin{tabular}{|l|l|l|l|}
\hline $\begin{array}{c}\text { Hal Yang } \\
\text { Dilakukan }\end{array}$ & Pengujian & $\begin{array}{c}\text { Kondisi Yang } \\
\text { Diinginkan }\end{array}$ & Hasil Pengujian \\
\hline Klik selesai & $\begin{array}{c}\text { Mengakhiri } \\
\text { latihan soal }\end{array}$ & $\begin{array}{c}\text { Latihan soal } \\
\text { diakhiri, kembali } \\
\text { ke halaman awal }\end{array}$ & $\begin{array}{l}{[\sqrt{ }] \text { berhasil }} \\
{[\text { ] tidak berhasil }}\end{array}$ \\
\hline Lihat Nilai & $\begin{array}{c}\text { Menampilkan } \\
\text { nilai dari } \\
\text { latihan soal }\end{array}$ & Nilai ditampilkan & $\begin{array}{l}{[\sqrt{ }] \text { berhasil }} \\
{[\text { ] tidak berhasil }}\end{array}$ \\
\hline
\end{tabular}

Hasil pengujian pada halaman data hadits terdapat pada tabel 8 .

Tabel 8. Hasil Pengujian Pada Halaman Data Hadits

\begin{tabular}{|c|c|c|c|}
\hline $\begin{array}{l}\text { Hal Yang } \\
\text { Dilakukan }\end{array}$ & Pengujian & $\begin{array}{c}\text { Kondisi Yang } \\
\text { Diinginkan }\end{array}$ & Hasil Pengujian \\
\hline $\begin{array}{c}\text { Klik tambah } \\
\text { data hadits }\end{array}$ & $\begin{array}{c}\text { Menampilkan } \\
\text { field inputan } \\
\text { judul dan isi } \\
\text { hadits }\end{array}$ & $\begin{array}{c}\text { Menampilkan } \\
\text { field inputan } \\
\text { judul dan isi } \\
\text { hadits }\end{array}$ & $\begin{array}{l}{[\checkmark] \text { berhasil }} \\
{\left[\begin{array}{ll}{[} & ] \text { tidak berhasil }\end{array}\right.}\end{array}$ \\
\hline $\begin{array}{l}\text { Klik edit } \\
\text { data hadits }\end{array}$ & $\begin{array}{c}\text { Menampilkan } \\
\text { field inputan } \\
\text { edit data hadits }\end{array}$ & $\begin{array}{c}\text { Menampilkan } \\
\text { field inputan } \\
\text { edit data hadits }\end{array}$ & 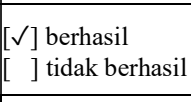 \\
\hline $\begin{array}{l}\text { Klik hapus } \\
\text { data hadits }\end{array}$ & $\begin{array}{l}\text { Menghapus } \\
\text { data hadits }\end{array}$ & $\begin{array}{c}\text { Data hadits } \\
\text { terhapus }\end{array}$ & $\begin{array}{l}{[\checkmark] \text { berhasil }} \\
{[\mathrm{]} \text { tidak berhasil }}\end{array}$ \\
\hline
\end{tabular}

Hasil pengujian pada halaman data soal terdapat pada tabel 9 .

Tabel 9. Hasil Pengujian Pada Halaman Data Soal

\begin{tabular}{|c|c|c|c|}
\hline $\begin{array}{l}\text { Hal Yang } \\
\text { Dilakukan }\end{array}$ & Pengujian & \begin{tabular}{|c|} 
Kondisi Yang \\
Diinginkan
\end{tabular} & Hasil Pengujian \\
\hline $\begin{array}{c}\text { Klik tambah } \\
\text { data soal }\end{array}$ & $\begin{array}{l}\text { Menampilkan } \\
\text { field inputan } \\
\text { soal dan } \\
\text { jawaban }\end{array}$ & $\begin{array}{l}\text { Menampilkan } \\
\text { field inputan } \\
\text { soal dan } \\
\text { jawaban }\end{array}$ & $\begin{array}{l}{[\sqrt{ }] \text { berhasil }} \\
{[\quad] \text { tidak berhasil }}\end{array}$ \\
\hline $\begin{array}{l}\text { Klik edit } \\
\text { data soal }\end{array}$ & $\begin{array}{l}\text { Menampilkan } \\
\text { field inputan } \\
\text { edit data soal }\end{array}$ & $\begin{array}{l}\text { Menampilkan } \\
\text { field inputan } \\
\text { edit data soal }\end{array}$ & $\begin{array}{l}{[\sqrt{ }] \text { berhasil }} \\
{[\quad] \text { tidak berhasil }}\end{array}$ \\
\hline $\begin{array}{c}\text { Klik hapus } \\
\text { data soal }\end{array}$ & $\begin{array}{c}\text { Menghapus } \\
\text { data soal }\end{array}$ & $\begin{array}{c}\text { Data soal } \\
\text { terhapus }\end{array}$ & $\begin{array}{l}{[\sqrt{ }] \text { berhasil }} \\
{[\text { ] tidak berhasil }}\end{array}$ \\
\hline
\end{tabular}

Hasil pengujian pada halaman data nilai terdapat pada tabel 10 .

Tabel 10. Hasil Pengujian Pada Halaman Data Nilai

\begin{tabular}{|c|c|c|c|}
\hline $\begin{array}{c}\text { Hal Yang } \\
\text { Dilakukan }\end{array}$ & Pengujian & \begin{tabular}{|c} 
Kondisi Yang \\
Diinginkan
\end{tabular} & Hasil Pengujian \\
\hline $\begin{array}{l}\text { lik hapus data } \\
\text { nilai }\end{array}$ & & $\begin{array}{l}\text { Data nilai } \\
\text { terhapus }\end{array}$ & \\
\hline
\end{tabular}

Untuk mengetahui presentase sukses total pegujian pada keseluruhan halaman pada aplikasi pembelajaran hadits dilakukan perhitungan sebagai berikut:

Presentase keberhasilan total $=24 / 24 \times 100 \%=$ $100 \%$

Presentase keberhasilan total selanjutnya dicocokan dengan pedoman Interprestasi Skor untuk mengetahui seberapa baik program yang sudah di uji pada tabel 11 
Tabel 11. Pedoman Interprestasi Skor Setelah Dikonversi

\begin{tabular}{|c|c|}
\hline Angka (\%) & Klasifikasi \\
\hline $0-20$ & Sangat Tidak Baik \\
\hline $21-40$ & Tidak Baik \\
\hline $41-60$ & Cukup Baik \\
\hline $61-80$ & Baik \\
\hline $81-100$ & Sangat Baik \\
\hline
\end{tabular}

Berdasarkan hasil pengujian blackbox menunjukan bahwa aplikasi pembelajaran hadits Arba'in Nawawi sudah befungsi dengan baik sesuai dengan hasil yang diharapkan.

\section{KESIMPULAN DAN SARAN}

\subsection{Kesimpulan}

Beberapa kesimpulan dari penelitian yang telah dilakukan ini adalah sebagai berikut :

1. Penelitian ini menghasilkan aplikasi pembelajaran hadits Arba'in Nawawi sebagai media pembelajaran santri yang praktis dan mudah digunakan. Aplikasi ini berfungsi sebagai media pembelajaran untuk santri agar para santri tidak mengalami kesalahpahaman dalam mempelajari hadits Arba'in Nawawi yang dilakukan secara online. Aplikasi pembelajaran hadits ini memuat beberapa fitur didalamnya yaitu, menyediakan materi hadits (arab, terjemahan dan syarah hadits), audio hadits, dan latihan soal yang gunanya untuk mengevaluasi pengetahuan para santri saat melakukan pembelajaran hadits. Aplikasi ini berbasis website yang dibuat dengan menggunakan framework codeigniter dan menggunakan bootstrap agar tampilan lebih dinamis, praktis dan mudah digunakan.

2. Pada penelitian ini dilakukan pengujian untuk melihat kelayakan aplikasi yang telah dibuat yaitu melakukan pengujian secara fungsional dengan menggunakan pengujian Blackbox. Hasil pengujian Blackbox ini mendapatkan tingkat kesesuaian sebesar $100 \%$ yang berati tergolong "sangat baik" dan hasil pengujian terhadap pengguna dan pakar materi mendapatkan hasil presentase sebesar $45 \%$ yang berarti "setuju" dan presentase $55 \%$ yang berarti "sangat setuju".

\subsection{Saran}

Dari penelitian ini tentunya terdapat banyak kekurangan, oleh sebab itu penulis memberikan saran untuk penelitian yang akan dilakukan berikutnya yaitu :

1. Melihat dari fitur yang terdapat di dalam aplikasi ini mungkin untuk kedepannya bisa dikembangkan lagi. Diantaranya aplikasi ini bisa ditambah fitur lain yang bisa membuat pembelajaran menjadi lebih menyenangkan, misalnya menambah gambar dan video yang berkaitan dengan hadits pada aplikasi ini.

2. Pengujian hanya berupa pengujian fungsional dengan pengujian Blackbox sehingga diharapkan pada penelitian berikutnya disarankan untuk menggunakan pengujian yang lebih beragam.

\section{DAFTAR PUSTAKA}

[1] Adri, S., 2017. Manhaj Imam An-Nawawi Dalam Kitab Al-Arba 'In An-Nawawiyyah: Kajian Filosofi di Balik Penulisan Kitab Hadis al-Arba 'in an-Nawawiyyah. AT-TAHDIS: Journal of Hadith Studies, 1(2).

[2] Syarif, M., 2017. Implementasi Algoritma String Matching Dalam Pencarian Surah Dan Ayat Dalam Al-Quran Berbasis Web. Indonesian Journal on Networking and Security, $6(2)$.

[3] Wahyuningsih, A.S. and Nurdiana, D., 2016. Aplikasi Pencarian dan Pembelajaran Hadist Pada Kitab Riyadhus Shalihin Berbasis Mobile. Jurnal Sisfokom (Sistem Informasi dan Komputer), 5(2), pp.21-26.

[4] Pane, A. and Dasopang, M.D., 2017. Belajar dan pembelajaran. Fitrah: Jurnal Kajian IlmuIlmu Keislaman, 3(2), pp.333-352.

[5] Burhannudin, A. and Indriati, M., 2019. Pencarian Terjemahan Hadits Shahih Muslim Menggunakan Metode Cosine Similarity Dengan Seleksi Fitur Term Frequency. Jurnal Pengembangan Teknologi Informasi dan Ilmu Komputer e-ISSN, 2548, p.964X.

[6] Daeli, M.M.Y. and Hondro, R.K., 2017. Perancangan Aplikasi Pencarian Kata Dengan Kombinasi Algoritma Knuth Morris Pratt Dan Algoritma Boyer Moore. Informasi dan Teknologi Ilmiah (INTI), 4(3).

[7] Febrian, V., Ramadhan, M.R., Faisal, M. and Saifudin, A., 2020. Pengujian pada Aplikasi Penggajian Pegawai dengan menggunakan Metode Blackbox. Jurnal Informatika Universitas Pamulang, 5(1), pp.61-66.

[8] Wahyudi, R., Utami, E. and Arief, M.R., 2016. Sistem pakar e-tourism pada Dinas Pariwisata DIY menggunakan metode Forward Chaining. Data Manajemen dan Teknologi Informasi (DASI), 17(2), pp.67-75.

[9] Pressman, R. S., 2015. Rekayasa Perangkat Lunak: Pendekatan Praktisi Buku I. Yogyakarta: Andi 